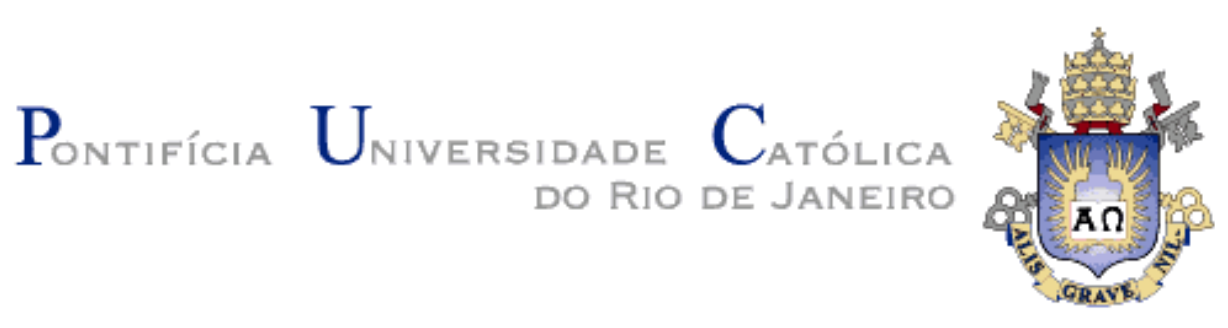

Juliana e Silva Pereira

\title{
A experiência escolar para jovens de camadas populares Um estudo em escola da Baixada Fluminense
}

Dissertação de Mestrado

Dissertação apresentada como requisito parcial para obtenção do grau de Mestre pelo Programa de PósGraduação em Educação do Departamento de Educação da PUC-Rio.

Orientador: Prof ${ }^{\mathrm{a}}$. Isabel Alice Oswald M onteiro Lelis

Rio de Janeiro

Junho de 2010 


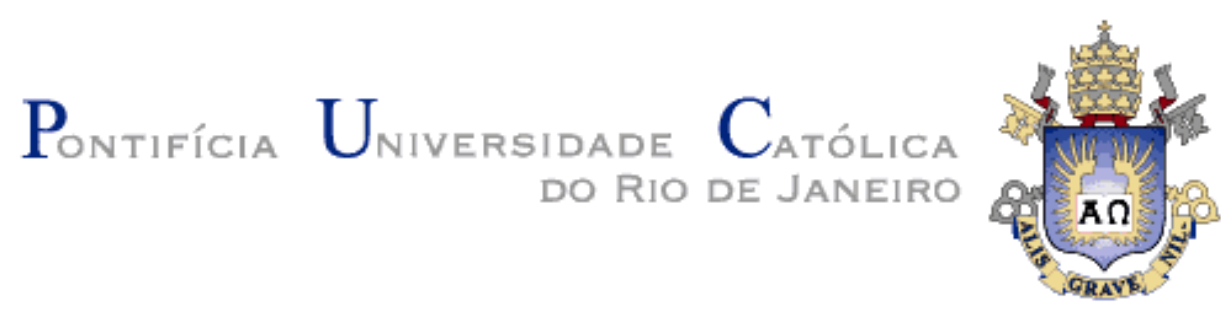

Juliana e Silva Pereira

\title{
A experiência escolar para jovens de camadas populares
}

Um estudo em escola da Baixada Fluminense

\begin{abstract}
Dissertação apresentada como requisito parcial para obtenção do grau de Mestre pelo Programa de PósGraduação em Educação do Departamento de Educação do Centro de Teologia e ciências Humanas da PUC-Rio. Aprovada pela Comissão Examinadora abaixo assinada.
\end{abstract}

Profa. Isabel Alice Oswald Monteiro Lelis
Orientadora
Departamento de Educação - Puc-Rio

Profa . Zaia Brandão

Departamento de Educação - Puc-Rio

Prof‥ Hustana Maria Vargas

UFF

Prof. Paulo Fernando Carneiro de Andrade

Coordenador Setorial do Centro de Teologia e Ciências Humanas

Puc-Rio

Rio de Janeiro, 24 de junho de 2010 
Todos os direitos reservados. É proibida a reprodução total ou parcial do trabalho sem autorização da universidade, da autora e do orientador.

\section{Juliana e Silva Pereira}

Graduou-se em História - Bacharelado e Licenciatura - no ano de 2006, pela Universidade Federal do Estado do Rio de Janeiro - UniRio. Especializou-se em História do Brasil pela Universidade Federal Fluminense - UFF - em 2008. Atualmente atua como professora do Ensino Fundamental e Médio, da rede pública e privada do Rio de Janeiro.

Ficha Catalográfica

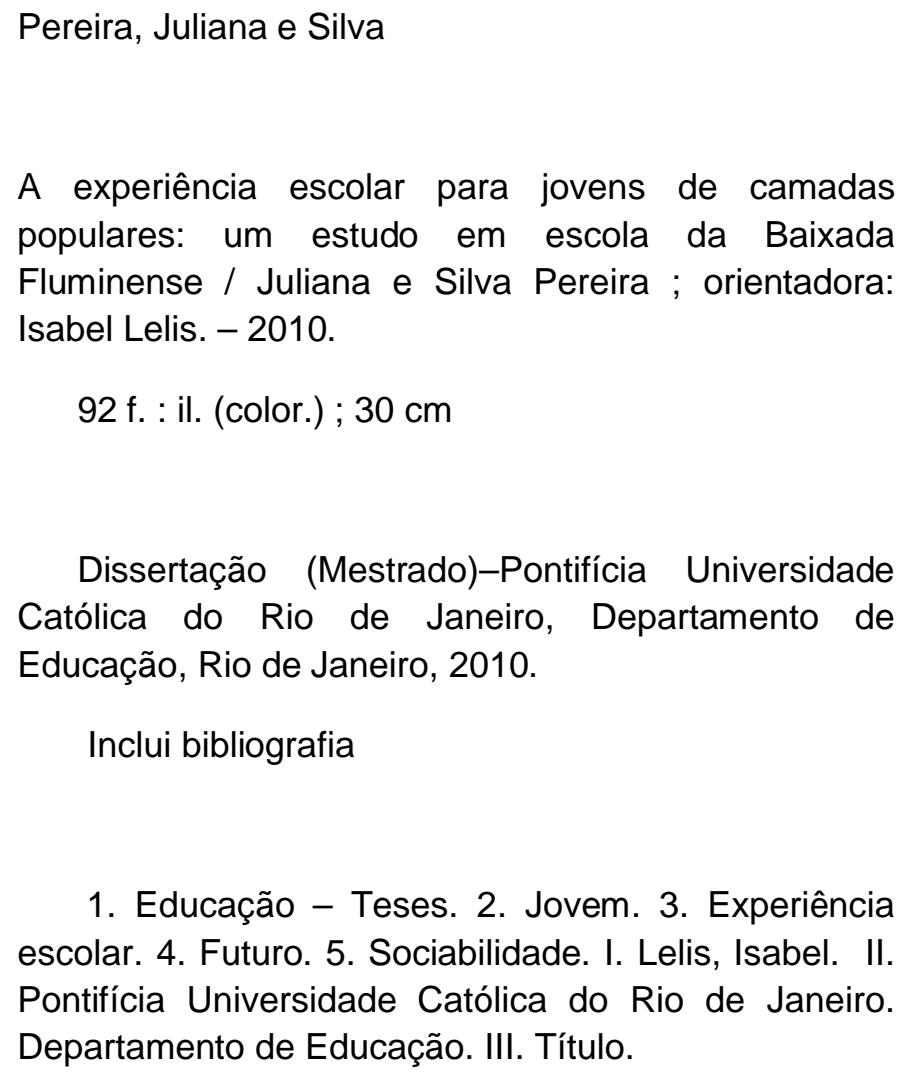

1. Educação - Teses. 2. Jovem. 3. Experiência escolar. 4. Futuro. 5. Sociabilidade. I. Lelis, Isabel. II. Pontifícia Universidade Católica do Rio de Janeiro. Departamento de Educação. III. Título. 
Aos meus pais, por darem sentido aos meus dias. Pelo incentivo, apoio e por me transformarem no que sou. 


\section{Agradecimentos}

Antes de tudo, a Deus, ser supremo, fiel escudeiro e amigo.

À minha professora Isabel Lelis, por todo incentivo, amizade e confiança. Você é um exemplo a seguir. Às agências financiadoras CNPq e FAPERJ, que me deram a oportunidade de me entregar por inteiro aos estudos. À Professora Zaia Brandão, por ceder o questionário do SOCED, material indispensável para a realização deste trabalho. Aos professores da banca examinadora. A todos os professores que tive durante minha vida que, de diversas formas, contribuíram para que este trabalho fosse realizado.

Aos meus pais, Marta e Antônio, pelo amor incondicional. Ao meu companheiro, Samuel, pela paciência e por acreditar em mim mais do que eu mesma acredito. À minha irmã querida, Mariana, pela companhia e amizade de toda uma vida.

Aos primos, tios e amigos, pela compreensão por todos os momentos de ausência que o compromisso com o estudo exigia. À prima e amiga Lidiane, pela companhia e sorriso aconchegante que me fazem relembrar a infância.

À amiga especial Adailda Gomes, que acompanhou toda minha trajetória no Mestrado e muito contribui para meu crescimento. Amizade rara e verdadeira. À amiga Erica Singui, pelas trocas de experiências, vivências e confidências. Aprendo com você a cada dia. À amiga Daniele da Anunciação, que tanto me ajudou a encontrar o ponto de equilíbrio, muitas vezes perdido. Amo você irmã.

Aos amigos da turma de Mestrado. Como aprendemos juntos! Aos amigos do GEPPE, pelas tardes alegres e troca de conhecimentos. A todos que, mesmo não sendo citados aqui, contribuíram de alguma forma para a realização deste trabalho.

Obrigada! 


\section{Resumo}

Pereira, Juliana e Silva. Lelis, Isabel Alice Oswald Monteiro. A experiência escolar para jovens de camadas populares: um estudo em escola da Baixada Fluminense. Rio de Janeiro, 2010. 92 p. Dissertação de Mestrado - Departamento de Educação, Pontifícia Universidade Católica do Rio de Janeiro.

Muito se fala sobre a crise da educação. Jornais, revistas, a mídia de forma geral vêm expondo os problemas pelos quais o sistema educacional vem passando. A quantidade de pesquisas envolvendo o tema é extensa, com estudiosos questionando a todo instante os motivos que levaram à crise, sua natureza, como superá-la. O processo de massificação e democratização da escola delineia-se como o ponto de viragem que marca o rompimento com o equilíbrio anteriormente estabelecido. Nesse processo, a escola passa a receber um contingente cada vez mais heterogêneo de alunos e, com eles, ambigüidades e paradoxos, permeados por uma diversidade de questões que desestabilizam a época das certezas. Sujeitos inseridos no contexto da crise da escola, professores e alunos não poderiam deixar de ser afetados por essas transformações. Autores como Bernard Charlot e Rui Canário afirmam que gradualmente foi ocorrendo um desencanto em relação à escola, que já não conseguia dar conta do prometido futuro profissional. Para os professores, os conflitos decorrentes dessa crise refletem-se diretamente em sala de aula, alterando suas condições de trabalho. Indisciplina, violência, dispersão seriam, certamente, sinais do desgaste, tanto para o professor quanto para os alunos. Diante desse contexto, o presente estudo buscou compreender qual seria o sentido da experiência escolar para jovens das camadas populares: qual a importância, qual papel a escola ocupa na vida desses jovens? Qual o significado da escola para seu futuro? Será que a escola ainda é percebida por esses jovens como esperança de mobilidade social? O que esses jovens esperam da escola? O objetivo maior dessa pesquisa foi justamente ouvir esses jovens, analisando quais seriam suas expectativas e angústias em relação à escola. Através de um estudo de inspiração etnográfica, de abordagem qualitativa - o trabalho de campo foi realizado em uma escola da Baixada Fluminense, 
periferia do Rio de Janeiro e baseou-se na observação das aulas, dos recreios e passeio pedagógico. Além disso, foi aplicado um questionário (buscando traçar um perfil socioeconômico dos jovens), e duas oficinas, em que os jovens relatavam e escreviam sua opinião sobre a experiência escolar - a presente pesquisa evidenciou que, mesmo diante de uma perda de legitimidade, a escola ainda representa para esses jovens oportunidade de ascensão social. A conquista de um diploma é o sentido da escola para eles. E é pensando no que esse diploma pode lhes proporcionar que vão à escola todos os dias. Para esses jovens a escola delineia-se como principal alternativa capaz de proporcionar uma sonhada mudança de vida. Dessa forma, o sentido da escola está associado ao futuro. No presente, o que mobiliza esses jovens a irem a escola seria a sociabilidade: o fazer amigos, o diálogo, as vivências. A escola seria o local de relacionamento com o outro, com a diversidade, lugar que possibilita troca de experiências, construção de identidade.

\section{Palavras-chave}

Jovem; experiência escolar; futuro; sociabilidade. 


\section{Abstract}

Pereira, Juliana e Silva. Lelis, Isabel Alice Oswald Monteiro (advisor). The school-experience of lower-class students: a research at a school in Baixada Fluminense. Rio de Janeiro, 2010. 92 p. Msc. Dissertation Departamento de Educação, Pontifícia Universidade Católica do Rio de Janeiro.

The education crisis has been an increasingly discussed current theme. Newspapers, magazines, all media, roughly speaking, has been exposing problems, which the education system has been going through. The amount of research on the topic is extensive - scholars have been incessantly questioning this crisis motives and its nature as well as possibilities to overpower it. The process of popularizing and democratizing school can be defined as the turning point, in which the rupture with the formely established equilibrium is characterised. It has been throughout this process that school started to admit a heterogeneous magnitude of students and, along with them, ambiguities and paradoxes loaded with a variety of issues that unsettled the age of certainties (reason). The ones inserted in the school crisis settings, for example teachers and students, are as a matter of course directly affected by such changes. According to authors like Bernard Charlot and Rui Canário, there has been a general gradual disenchantment concerning school - considering it does not account for the promisse of "future professional success" any longer. From the teacher's perspective, crisis-resulting conflicts are instantaneously reproduced in the classroom, thus altering their working condition. Presumably are indiscipline, violence and lack of concentrarion, signs of weariness from both teacher and student. Regarding the above depicted scenario, the present research implicates an attempt to the understanding of that what would be the meaning of schoolexperience to lower-class students. Namely, the answering of the following questions: Why does school matter? Which role does school play in these students lives? What does school mean to their futures? Do the students still perceive school as hope for social mobility? What do these students expect from 
school? The research main target involves listening to these students and then analysing their angst and expectations towards school. Inspired on ethnographics and with a qualitative approach, the fieldwork took place at a school located in one of the suburbs of Rio de Janeiro called Baixada Fluminense, where lessons, recreation as well as school excursions were attentively observed. In addition, the students have received an inquiry (for the drawing out of social-economic profile from the students) and took part in two workshops, where they were given the chance to write down and report their opinions on their own experiencing of school. The results evidence that, despite a certain loss of legitimacy, school still represents an opportunity of social assension to the students. Earning a school leaving certificate was revealed to be the meaning of school and it is with their thoughts on what this certificate could provide them in the future that they go to school everyday. All in all, school is portrayed as the major opportunity to reach a so desired "changing of life". Therefore, the meaning of school is associated with the future. Presently, it is sociability that motivates students to keep going to school: making friends, conversations, experiences. Accordingly, school turns out to be the place where contact with others, with diversity - in other words, relationship - happens; the place where experiences are exchanged and identity constructed.

\section{Keywords}

Youth-school; experiencing-school; future; sociability. 


\section{Sumário}

1. Introdução 13

1.1. Experiências de uma pesquisadora iniciante $\quad 13$

1.2. Localizando a questão 15

2. Fundamentação teórico-metodológica 21

2.1. Estudos sobre a escola - o aluno como ator 21

2.2. Caminhos da pesquisa 25

3. Conhecendo - explorando o universo pesquisado 30

3.1. O Colégio Tupinambá - breve história da escola 30

3.2. Estrutura física 32

3.3. Organização 35

4. A entrada na escola 38

4.1. Estagiária 38

4.2. Vigia 39

4.3. Professora 41

4.4. Os sujeitos 42

5. O sentido da experiência escolar 46

5.1. Quem são eles, afinal? 46

5.2. Onde tudo começa 48

5.3. Um futuro "sonhado" 51

5.4. Um presente "vivido" 65

6. Considerações finais 71

6.1. Entre o presente vivido e o futuro sonhado 71

$\begin{array}{ll}\text { Referências bibliográficas } & 77\end{array}$

$\begin{array}{ll}\text { Anexos } & 81\end{array}$ 


\section{Lista de tabelas e gráficos}

$\begin{array}{ll}\text { Gráfico } 1 & 43\end{array}$

Gráfico 2

$\begin{array}{ll}\text { Tabela } 1 & 53\end{array}$

$\begin{array}{lr}\text { Tabela } 2 & 56\end{array}$

$\begin{array}{ll}\text { Tabela } 3 & 61\end{array}$

$\begin{array}{ll}\text { Tabela } 4 & 63\end{array}$

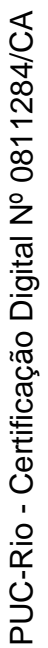


A escola é vida, uma parte da vida.

Phillippe Perrenoud 